\title{
KETAHANAN PANGAN PETANI PADI SAWAH: SEBUAH PENELITIAN TERAPAN UNTUK MENEMUKAN MODEL GARIS KETAHANAN PANGAN DI SULAWESI UTARA
}

\author{
Elsje Pauline Manginsela \\ Oktavianus Porajouw \\ Benny Adrian Berthy Sagay
}

\begin{abstract}
This study aims to: calculate the amount of rice consumption per capita per year of rice farmers; to increase knowledge about when lowland rice farmers experience a shortage of rice and cannot afford rice because there is no purchasing power what they do to overcome it?; to measure the level of food security and the ratio of fear to the families of lowland rice farmers. This research was conducted from July to November 2018 in Mopait Village and Pangian Village. which is one of the rice-producing villages in Bolaang Mongondow Regency, North Sulawesi. This research used quantitative and qualitative data collection methods concerning the production, fulfillment of rice consumption and the sale and purchase of rice at the level of the rice paddy farmer family. Interviews were conducted with farmers and village leaders as primary data sources. While the secondary data sources came from the Central Sulawesi Statistics and Agriculture Office of North Sulawesi. Data analysis uses quantitative and qualitative data analysis approaches. Quantitative and Qualitative Modeling of Food Security Lines and Farmer Fear Ratio. By using this Food Resilience Line Model, it will be known whether the Family Food Security of Paddy Farmers is strong or weak. Calculation of Farmer's Fear Ratio to find out whether farmers are pessimistic or optimistic about fulfilling rice consumption needs. The results showed that the amount of rice consumption per capita per year for paddy rice farmers, in Mopait Village rice consumption was 121 rice per capita per year. Whereas rice farmers in Pangian Village consume rice with $185 \mathrm{~kg}$ of rice per capita per year. At a time when lowland rice farmers lack rice and cannot afford to buy it at the market, they will borrow rice from the mill. The line of food security in the two research villages shows different figures in Mopait Village $>1$ while in Pangian Village <1. This means that the level of food security in paddy rice farming families in Mopait Village is higher than Pangian Village. While the paddy rice farmers in Mopait Village this year felt less fear compared to 5 years ago but for the next 5 years they remain more pessimistic than this year. Rice farmers in Pangian are more optimistic.
\end{abstract}

Keywords: Line of Food Security, Farmer Fear Ratio, Paddy Rice Farmer Family, North Sulawesi

\section{ABSTRAK}

Penelitian ini bertujuan untuk: menghitung berapa jumlah komsumsi beras per kapita per tahun petani padi sawah; untuk meningkatkan pengetahuan tentang kapan petani padi sawah mengalami kekurangan beras dan tidak mampu membeli beras karena tidak ada daya beli apa yang mereka lakukan untuk mengatasinya?; untuk mengukur tingkat ketahanan pangan dan rasio ketakutan pada keluarga petani padi sawah. Penelitian ini dilaksanakan dari bulan Juli sampai November 2018 di Desa Mopait dan Desa Pangian. yang termasuk desa penghasil padi sawah di Kabupaten Bolaang Mongondow, Sulawesi Utara. Penelitian ini menggunakan metode pengumpulan data kuantitatif dan kualitatif menyangkut produksi, pemenuhan konsumsi beras dan penjualan serta pembelian beras di tingkat keluarga petani padi sawah. Wawancara dilakukan pada petani dan pemimpin desa sebagai sumber data primer. Sedangkan sumber data sekunder berasal dari Badan Pusat Statistik dan Kantor Pertanian Sulawesi Utara. Analisa data menggunakan pendekatan analisa data kuantitatif dan kualitatif. Pemodelan Kuantitatif dan Kualitatif tentang Garis Ketahanan Pangan serta Rasio Ketakutan Petani. Dengan menggunakan Model Garis Ketahanan Pangan ini maka akan dapat diketahui apakah Ketahanan Pangan Keluarga Petani Padi Sawah tergolong kuat atau lemah. Perhitungan Rasio Ketakutan Petani untuk mengetahui apakah petani pesimis atau optimis menyangkut pemenuhan kebutuhan konsumsi beras. Hasil penelitian menunjukkan bahwa jumlah komsumsi beras per kapita per tahun petani padi sawah, dari petani padi di Desa Mopait, konsumsi berasnya adalah 121 beras per kapita per tahun. Sedangkan petani padi sawah di Desa Pangian konsumsi berasnya adalah $185 \mathrm{~kg}$ beras per kapita per tahun. Pada saat petani padi sawah kekurangan beras dan tidak mampu membeli di pasar maka mereka akan meminjam beras di penggilingan. Garis ketahanan pangan di dua desa penelitian menunjukkan angka yang berbeda di Desa Mopait $>1$ sedangkan di Desa Pangian $<1$. Artinya Tingkat ketahanan pangan pada keluarga petani padi sawah di Desa Mopait lebih tinggi dibandingkan dengan Desa Pangian. Sedangkan Petani padi sawah di Desa Mopait tahun ini rasa ketakutannya lebih berkurang dibandingkan 5 tahun yang lalu. Tetapi untuk 5 tahun yang akan datang mereka tetap lebih pesimis dibandingkan tahun ini. Petani padi sawah di Pangian lebih optimis.

Kata kunci: Garis Ketahanan Pangan, Rasio Ketakutan Petani, Keluarga Petani Padi Sawah, Sulawesi Utara

Agrisosioekonomi:

Jurnal Transdisiplin Pertanian (Budidaya Tanaman, Perkebunan, Kehutanan, Peternakan, Perikanan), Sosial dan Ekonomi 193 


\section{PENDAHULUAN}

\section{Latar Belakang}

Ketahanan pangan nasional merupakan keadaan yang sangat penting bagi kelangsungan Negara Kesatuan Republik Indonesia (NKRI). Apabila ketahanan pangan lemah, dapat dipastikan berbagai gejolak sosial ekonomi dan politik akan terjadi. Ujungnya adalah ambruknya NKRI. Karena itu bagaimanapun juga upaya memperkuat ketahanan pangan secara riil di lapangan adalah hal mutlak harus di jaga.

Beberapa bulan yang lalu, realitas harga beras sempat bergejolak. Data ketersediaan beras sempat dipertanyakan keakuratannya (Kompas, 23 Desember 2017. https://www. pressreader.com/ indonesia/kompas/20171223 /281908773510068). Beberapa instansi yang memiliki data ketersediaan beras, ternyata berbeda-beda secara signifikan. Kalau datanya saja sudah berbeda-beda dan masingmasing instansi mengaku yang paling betul, maka hal ini merupakan kerawanan dalam wujud lain. Bisa jadi data tersebut tidak sesuai dengan kenyataan di lapangan.

Tampaknya hanya tinggal menunggu waktu saja untuk sampai pada keadaan terjadinya krisis ketersediaan beras (pangan) secara nyata. Mengapa? Karena sesuai data, pemerintah masih mengganggap aman-aman saja. Padahal di lapangan sebenarnya beras sudah kosong. Impor secara dadakan memang bisa dilakukan. Tetapi tidak akan selalu bisa mengatasi krisis secara cepat, karena harus berhadapan dengan mekanisme pasar global dan transportasi yang rumit. Belum lagi dikhawatirkan mafia-mafia pangan ikut ambil peranan memperkeruh dan memperdalam krisis ketersediaan pangan. Mungkin inilah gambaran betapa ketahanan pangan di tingkat lokal, regional sampai nasional sangat perlu diperkuat.

Hulu dari ketahanan pangan (beras) adalah ketahanan pangan keluarga petani padi sawah. Bagaimana mungkin Ketahanan Pangan khususnya beras bisa dikatakan kuat dan stabil, kalau ketahanan pangan keluarga petani padi sawah masih belum menentu. Sampai kapanpun ketergantungan rakyat Indonesia pada petani padi sawah tetap tinggi sampai suatu ketika kelak, mungkin zat tepung bisa di buat secara sintetik dengan cara ada pabrik yang bisa meniru cara tanaman padi memproduksi tepung. Hal ini sudah diteliti oleh para ilmuwan sejak puluhan tahun yang lalu tetapi nampaknya belum berhasil ditemukan. Kuncinya adalah rahasia kloropil dalam proses fotosintesa. Siapa tahu yang berhasil menemukan kelak adalah ilmuwan Indonesia khususnya Unsrat.

Betapa pentingnya mengetahui ketahanan pangan di tingkat petani padi sawah sebagai komponen utama penyusun ketahanan pangan di tingkat desa sampai tingkat nasional. Masyarakat Indonesia pada umumnya menganggap beras merupakan makanan pokok yang memiliki gengsi yang lebih tinggi dibandingkan dengan makanan pokok lainnya seperti singkong, ubi jalar dan talas (Manginsela, 2017). Sehubungan dengan hal inilah penelitian dan pemodelan ketahanan pangan, khususnya beras, sangat perlu dilakukan.

\section{Perumusan Masalah}

Sampai saat ini, sering dihebohkan tentang data ketersediaan pangan (beras) secara nasional. Biasanya masing-masing pejabat saling tuding untuk membenarkan dirinya sendiri. Namun dibalik semua kegaduhan itu, kita tidak pernah mempermasalahkan: apakah kita sudah memiliki data mikro yang benar-benar berasal dari petani padi?

\section{Tujuan Penelitian}

Penelitian ini bertujuan untuk meningkatkan pengetahuan tentang:

Penelitian ini bertujuan untuk meningkatkan pengetahuan tentang:

1. Jumlah komsumsi beras per kapita per tahun petani padi sawah? 
2. Bila petani padi sawah mengalami kekurangan beras dan tidak mampu membeli beras karena tidak ada daya beli apa yang mereka lakukan?

3. Mengukur tingkat ketahanan pangan dan rasio ketakutan pada keluarga petani padi sawah.

\section{Manfaat Penelitian}

Penelitian ini menjadi penting karena temuan dari studi ini secara khusus diharapkan dapat menjadi bahan rekomendasi pada para pengambil keputusan yang berkaitan dengan kebijakan dan program di bidang pangan terlebih khusus ketahanan pangan agar dapat berkelanjutan serta dapat meningkatkan efisiensi dan efektifitas dalam pelaksanaan program-programnya.

\section{METODE PENELITIAN}

\section{Lokasi dan Waktu Penelitian}

Penelitian ini dilaksanakan selama 6 bulan dimulai pada bulan Juni sampai bulan November 2018, di dua desa yang terletak di dua Kecamatan di Kabupaten Bolaang Mongondow yang merupakan Kabupaten penghasil beras terbanyak di Sulawesi Utara yaitu Desa Mopait di Kecamatan Lolayan dan Desa Pangian di Kecamatan Passi Timur.

\section{Pengumpulan data kuantitatif dan kualitatif serta prosedur pengumpulan data}

Pengumpulan data kuantitatif dan kualitatif terdiri atas pengumpulan data menyangkut produksi, konsumsi, penjualan dan pembelian beras pada keluarga petani serta pengalaman petani padi sawah sehubungan dengan komsumsi pangan keluarga terutama beras.

\section{Pengumpulan data kuantitatif dan kualitatif menyangkut produksi dan konsumsi beras}

Penelitian ini mengumpulkan informasi rinci menyangkut produksi, konsumsi, penjualan dan pembelian beras di tingkat keluarga petani. Penelitian ini merupakan penelitian cross sectional dimana melakukan penelitian pada suatu waktu tertentu (Neuman 2007). Penelitian ini menggunakan dua jenis data yaitu data primer dan data sekunder. Data primer akan dikumpulkan dari tiga desa dengan menggunakan pendekatan kuantitatif berupa wawancara dengan bantuan pedoman wawancara. Sumber data sekunder berasal dari instansi pemerintah (provinsi, kabupaten, kecamatan dan desa), lembaga swadaya masyarakat/organisasi pencinta lingkungan, perpustakaan/internet, serta skripsi yang dilakukan pada lokasi penelitian. Seperti disebutkan sebelumnya, penelitian ini terutama didasarkan pada data primer dengan melakukan wawancara dan pengamatan. Wawancara dilakukan pada petani padi sawah. Wawancara mendalam dilakukan pada pemimpin masyarakat desa. Pemimpin Desa adalah pemimpin formal dan nonformal/informal dengan latar belakang pemerintahan, pendidikan dan agama (Toma).

Pengumpulan data primer dari dua lokasi penelitian akan menggunakan:

a. Wawancara individual pada petani padi sawah

Wawancara dengan menggunakan panduan wawancara pertanyaan terbuka untuk menggali dan menggambarkan jawaban dari keluarga petani padi sawah. Daftar pertanyaan dikembangkan oleh tim peneliti dan akan ditanyakan dengan cara tatap muka. Jumlah petani setiap desa terdiri atas 50 petani padi sawah. Total dari 2 desa adalah 100 responden.

b. Wawancara mendalam dari pemimpin masyarakat sebagai informan kunci

Wawancara mendalam akan dilakukan pada pemimpin desa. Para pemimpin desa dengan latar belakang berbeda yaitu pemerintahan. Pendidikan, dan agama yang memiliki pengetahuan tentang pertanian padi sawah. Ketiga lembaga ini dipilih karena memainkan peranan penting dalam kehidupan keseharian masyarakat. Para pemimpin desa diharapkan menyediakan informasi umum yang penting tentang desa, 
masyarakat dan hubungan antara masyarakat setempat dan lembaga di luar desa yang berkaitan dengan kegiatan petani padi sawah. Dan total dari 3 desa adalah 3 informan kunci yang berlatar belakang pemimpin desa. Apabila diperlukan maka akan diambil pemimpin masyarakat yang berlatar belakang organisasi sosial dan organisasi kepemudaan serta pemimpin yang berada di atas tingkat desa baik dari propinsi, kabupaten, dan kecamatan dengan latar belakang pertanian padi sawa dan lembaga swadaya masyarakat yang berkaitan dengan usaha tani padi sawah atau lembaga pemasaran padi sawah.

\section{Pengumpulan data kuantitatif dan kualitatif menyangkut penjualan dan pembelian beras}

Pengumpulan data menyangkut penjualan dan pembelian beras dalam satu tahun di tiga lokasi penelitian menyangkut berapa banyak komsumsi beras keluarga petani per tahun? Berapa banyak beras yang dikonsumsi itu berasal dari produksi sendiri dan berapa banyak yang dibeli di pasar. Kapan biasanya membeli beras dan selama berapa bulan. Pernahkah petani padi sawah mengalami kekurangan beras dan tidak mampu membeli beras di pasar karena tidak ada daya beli? Kapan itu terjadi?

\section{Prosedur pengumpulan data penelitian}

Tahapan yang dilakukan dalam penelitian ini adalah sebagai berikut:

(1) Persiapan dan kegiatan pra-penelitian, antara lain, dengan menginformasikan kegiatan penelitian ditingkat kabupaten, kecamatan dan desa. Di tingkat desa, menginformasikan pada pimpinan dan masyarakat desa termasuk keluarga petani;

(2) Pelaksanaan pengumpulan data dengan wawancara dan pengamatan;

(3) Input dan Pengolahan data;

(4) Analisa data dan interpretasi, dan

(5) Penyusunan laporan.

\section{Analisis Data}

Selama ini dikenal garis kemiskinan Bapak Professor Sajogyo, garis kemiskinan Bank Dunia, garis kemiskinan BPS. Dalam penelitian ini dicoba dibangun Pemodelan Kuantitatif tentang garis ketahanan Pangan.

Pengumpulan data primer akan dianalisa berdasarkan (1) Rumus Ketahanan Pangan dan (2) Rasio Ketakutan Petani yaitu:

Perhitungan berdasarkan Rumus Ketahanan Pangan berikut ini:

\section{(1) Rumusan Ketahanan Pangan}

$\mathrm{KP}=$ Produksi Beras - Beras yang dijual

$\mathrm{KKT}=$ Komsumsi Beras Keluarga

$\mathrm{KP}=$ Kecukupan Pangan

$\mathrm{KKT}=$ Komsumsi Keluarga

Garis Ketahanan Pangan $(\mathrm{GKP})=\frac{\mathrm{KP}}{\text { Konsumsi Keluarga }}$

Nilai GKP $<1$ artinya lemah

Nilai GKP $=1$ artinya sama dengan garis ketahanan pangan

Nilai GKP > 1 artinya kuat

Perhitungan berdasarkan Rumus Ratio Ketakutan Petani (RKP) yaitu:

\section{(2) Rasio Ketakutan Petani}

RKP > 1 berarti suasana menunjukkan optimis tidak ketakutan.

RKP $<1$ berarti suasana menunjukkan pesimis ketakutan.

\section{HASIL DAN PEMBAHASAN}

\section{Petani sebagai Produsen: Bertahan dalam bias pembangunan}

Petani sebagai produsen kelihatan telah semakin menua usianya, berkisar 50-60 tahun. Pendidikan petani renta ini hanya berkisar Sekolah Dasar dan SMP. Petani yang lebih muda pendidikannya ada yang sama 
dengan orangtuanya yaitu Sekolah Dasar ada juga yang lebih baik yaitu SMA. Tampaknya generasi yang lebih muda memilih terjun menjadi petani karena sudah tidak ada pilihan lain. Namun di Desa Pangian tingkat pendidikan petani lebih baik bahkan ada lulusan sarjana menjadi petani. Desa Pangian menunjukkan situasi sosial yang lebih baik karena petani pemilik penggarap masih relatif lebih banyak. Sedangkan di Desa Mopait, petani penggarap yang tidak memiliki sawah sendiri relatif banyak. Berdasarkan wawancara informal ternyata lahan pertanian sudah banyak yang berpindah tangan ke pihak lain baik sesama warga desa maupun luar desa bahkan ada pemiliknya orang kota. Selama keberadaan lahan sawah dipertahankan oleh pemilik baru, pengaruhnya pada produksi beras tidak besar. Tetapi kalau lahan itu hanya dijadikan investasi dan setiap saat siap dijadikan lahan non-pertanian maka hal ini menjadi pukulan bagi ketahanan pangan khususnya beras.

Fenomena buramnya ketahanan sosial ekonomi petani tidak lepas dari ketahanan pangannya. Bila ketahanan pangannya lemah maka sedikit saja ia mengalami goncangan usahanya karena sakit atau menyekolahkan anak, maka ia akan tenggelam (menjual) sawahnya dan akhirnya petani ini menjadi penggarap bagihasil di tanahnya sendiri.

Kalau dilihat dari indikator kesejahteraan sosial, kelihatan petani pemilikpenggarap umumnya menghuni rumah permanen sedangkan petani penggarap menghuni rumah semi-permanen. Bagaimana kalau petani padi yang menjadi kunci ketahanan pangan sudah semakin renta, semakin rawan ditimpa bencana kemiskinan dan semakin kalah menghadapi pasar? Pangan beras tidak bisa ada dengan sendirinya tetapi memerlukan campur tangan petani untuk memproduksinya. Hal inilah yang menjadi tantangan kebijakan pertanian khususnya beras agar kelak petani padi tidak selalu miskin dan kalah menghadapi pasar.
Jika sawah dibeli oleh orang nonpertanian yang sengaja menjadikan sawah sebagai aset investasi maka sawah sudah kehilangan "roh"nya. Roh sawah adalah sebagai penyedia bahan pangan bagi manusia petani dan non-petani di kota-kota. Bila sawah sudah beralih fungsi sebagi aset investasi yang dikendalikan oleh orang kota maupun investor dalam desa, maka cepat atau lambat sawah akan beralih fungsi mengikuti tren pasar. Yang pasti tren pasar sawah sebagai penghasil pangan, kalah jauh dibandingkan tren pasar sawah sebagai tempat perumahan, pabrik maupun jalan raya. Jika sawah berada ditangan petani, maka sawah sebagai lahan pertanian mempunyai roh. Petani memperlakukan sawah sebagai bagian dari jiwa raganya. Karena bersamasama dengan sawah, petani mengayuh kehidupan hari demi hari sampai ajal menjemputnya dan kemudian diwariskan kea anak-anaknya.

Apa gerangan yang menyebabkan petani rela melepaskan penggalan jiwa raganya yaitu sawah untuk di jual ke orang lain. Apakah sesama petani atau nonpertanian? Disinilah letak bias pembangunan pertanian khususnya pertanian beras (padi) selama ini. Pembuat kebijakan terlalu memanjakan pihak non-pertanian dengan harga beras murah dengan harapan suatu ketika kelak setelah non-pertanian mengalami peningkatan taraf hidup dampaknya akan menetes ke petani padi. Ternyata tetesan itu tidak pernah sampai ke petani malahan sebaliknya petani diperas terus menerus untuk "menyusui" pihak non-petani yang terlalu manja dan selalu sebagai balita tidak pernah menjadi masyarakat dewasa yang makmur.

Negara-negara Asia Timur yang saat ini sudah kaya dan makmur sebagai negara industri, pada mulanya juga "menyusu" pada petani padi. Namun setelah berhasil makmur, pembuat kebijakan tidak pernah ingkar janji untuk membalas jasa petani melalui kebijakan-kebijakan pembangunan pertanian, misalnya harga beras yang mahal dan beras dari luar negeri yang lebih murah sengaja 
diproteksi oleh tarif yang mahal. Dengan demikian petani tanaman pangan terlindungi dan ikut merasakan tetesan kemakmuranyang dihasilkan oleh masyarakat non-pertanian (masyarakat industri) yang telah dewasa. Masyarakat industri Indonesia tidak pernah dewasa selalu berperilaku anak-anak bahkan balita, dan perlu terus menerus disubsidi oleh petani padi entah sampai kapan. Karena itu bersamaan dengan bias-bias pembangunan pertanian itu, lahan pertanian kalah pamor dibandingkan dengan sebagian lahan nonpertanian.

Pemerintah tidak mungkin menaikkan harga beras setinggi-tingginya sehingga merangsang petani padi untuk berproduksi, karena masyarakat non-pertanian yang memerlukan pangan masih belum kuat daya belinya sebagai akibatnya pemerintah puluhan tahun menerapkan kebijakan harga beras yang stabil di level murah. Hal ini membuat masyarakat non-pertanian merasa keamanan pangannya terjamin. Bahkan petani sendiri berani menjual sebagian besar produksi padinya sesaat setelah panen dan nantinya petani membeli beras kalau persediaan sudah habis.

Fenomena ini nampak di desa penelitian dan terjadi di hampir seluruh pusat pertanian padi. Hal ini bisa ditafsirkan petani padi telah menggantungkan harapannya kepada pasar. Pasarlah yang saat ini menjadi lumbung petani karena kalau persediaan beras habis petani bisa dengan mudah membeli beras di penggilingan atau di pasar-pasar. Masalahnya kalau daya beli tidak ada bagaimana? Tampaknya penggilingan mempunyai cara untuk memberi pinjaman sehingga petani terikat untuk menggiling ke penggilingan itu pada panen-panen berikutnya.

\section{Garis ketahanan pangan: bagaimana kalau petani padi sawah saja sudah lemah apalagi non-petani}

Garis ketahanan pangan di dua desa penelitian menunjukkan angka yang berbeda di Desa Mopait > 1 sedangkan di Desa Pangian < 1. Lihat Tabel 1.
Tabel 1. Garis ketahanan pangan

\begin{tabular}{lcc}
\hline Garis ketahanan pangan & \multicolumn{2}{c}{ Desa } \\
\cline { 2 - 3 } & Mopait & Pangian \\
\hline \multirow{2}{*}{ Kecukupan pangan (KP) } & ---- kg beras/tahun-------- \\
Konsumsi Beras Keluarga (KBK) & 628 & 400 \\
\hline Garis Ketahanan Pangan (GKP) & 486 & 740 \\
\hline
\end{tabular}

Bila garis ketahanan pangan $>1$ berarti petani padi sawah mempunyai ketahanan pangan kuat. Semakin besar angka diatas 1 semakin kuat ketahanan pangannya. Petani di Desa Mopait hanya berada 0,29 di atas angka 1 hal ini menunjukkan kekuatan ketahanan pangannya hanya berada sedikit di atas garis batas. Bila suatu ketika ada gangguan produksi sedikit saja, misalnya karena serangan hama penyakit padi, gangguan iklim maupun kekurangan modal membeli sarana produski bisa berarti petani mudah terjatuh ke bawah garis ketahanan pangan. Berarti pertanian padinya tidak bisa memenuhi kebutuhan keluarganya, sehingga harus berusaha memenuhinya melalui pekerjaan non-pertanian atau meminjam lebih banak lagi dari penggilingan atau toko (pasar).

Petani padi sawah di Desa Pangian nasibnya lebih buruk. Mereka berada di bawah garis ketahanan pangan. Berarti sekalipun mereka tercatat sebagai petani padi tetapi pemenuhan kebutuhan pangannya bergantung pada pasar, bukan bergantung pada sawah sendiri. Keadaan yang memiriskan ini menyebabkan tinggal menunggu waktu saja, lahan sawah akan jatuh ke tangan pemodal karena dijual oleh petani. Petani padi sawah di Desa Pangian sangat dalam tenggelam di bawah garis ketahanan pangan karena jaraknya cukup jauh dari angka satu.

Kejadian ini disebabkan tradisi menjual sebagian besar hasil panen (sekitar 70-80\%) pada saat selepas panen. Hal ini berarti petani membutuhkan uang tunai untuk berbagai keperluan. Karena harga beras relatif stabil maka petani tidak terlalu menghiraukan kalau nantinya harus memberi beras pada bulanbulan berikutnya. 
Bila produktivitas bisa ditingkatkan dan luas pemilikan lahan bisa bertambah, garis kecukupan pangan akan naik. Tetapi upaya ini tidak mudah. Peningkatan produktivitas memerlukan input yang lebih besar ini berarti tambahan modal. Sedangkan perluasan pemilikan lahan lebih sulit lagi, bahkan kenyataanya yang terjadi justru pemilikan semakin sempit karena dijual. Bahkan banyak yang tadinya petani pemilik-penggarap berubah menjadi petani penggarap tanpa lahan sendiri.

Kalau petani padi sendiri ketahanan pangannya sudah rendah maka masyarakat non-petani kita ketahanan pangannya akan rendah juga. Sebagai akibatnya pemerintah harus melakukan impor beras guna menutupi kelemahan ketahanan pangan. Berarti ketahanan pangan telah beralih ke pasar. Tadinya hanya berkisar antara petani, sawah dan keluarga petani. Setelah ada intervensi dari pemerintah (kebijakan) maka masuklah musim pasar dan kendali harga lewat lumbung pangan nasional (Bulog). Kebiasaan untuk menjual hasil panen padi dalam jumlah besar dan selepas panen mempunyai dampak berputarnya uang tunai dari desa menuju ke segala arah. Misalnya setelah menjual beras, petani membeli hasil industri atau membayar uang sekolah anaknya di kota. Berarti ada aliran energi pasar dari desa ke kota sehingga menghidupkan perputaran ekonomi nasional. Namun sektor luar desa (industri) selalu menghisap lebih rakus energi pasar dari desa. Produk pertanian apalagi beras yang dikendalikan pemerintah, tidak bisa membuat kejutan seperti petani kopi, cengkih, pala dan lain-lain. Petani cengkih bisa tiba-tiba menjadi kaya raya bila harga cengkih melonjak secara drastis, demikian juga bisa tiba-tiba gigit jari bila harga cengkeh anjlok di bawah harga pokok produksi.

Swasembada beras berarti meningkatkan ketahanan pangan petani melampaui garis angka $1(>1)$ hal ini wajib diupayakan. Kalau tidak demikian ketergantungan pada impor dari luar negeri maupun suplai dari daerah lain menunjukkan bahaya laten yang bisa tiba-tiba bisa menjadi nyata yaitu tidak terkendalinya harga panen dan pangan hilang dari pasaran,

Fenomena semakin banyaknya petani padi yang menjual sawahnya, perlu mendapat perhatian. Salah satunya dengan cara perlindungan terhadap lahan sawah agar tidak dengan gampangnya dialihfungsikan menjadi non-pertanian. Lahan sawah yang produktif jangan sampai dibiarkan mejadi lahan tidur karena yang empunya hanya menunggu harga lahan naik dan menjualnya kembali. Ini tidak ubahnya lahan sawah telah menjadi obyek investasi. Padahal di lahan sawah itu sebenarnya adalah belahan jiwa petani, bukan keserakahan pemilik modal untuk menunggu keuntungan yang lebih besar lagi.

\section{Konsumsi beras per kapita}

Konsumsi beras per kapita per tahun menggambarkan tingkat kemakmuran suatu masyarakat. Semakin makmur masyarakat biasanya konsumsi beras semakin berkurang digantikan dengan protein, buah, susu dan lain-lain. Bahkan di masyarakat maju di negara lain tingkat konsumsi besarnya sangat kecil misalnya bangsa Jepang, padahal beberapa ratus tahun lalu, keadaan di Jepang mirip dengan keadaan saat ini di Indonesia.

Petani padi di Desa Mopait, konsumsi berasnya adalah 121 beras per kapita per tahun. Petani padi di Desa Pangian konsumsi berasnya adalah $185 \mathrm{~kg}$ beras per kapita per tahun. Dibandingkan dengan konsumsi beras per kapita tingkat nasional pada tahun 2017, menurut BPS, yang sebesar 114,6 kg per kapita per tahun maka konsumsi beras per kapita pertahun di kedua desa berada di atas angka nasional. Sedangkan konsumsi beras per kapita pertahun rata-rata per provinsi pada tahun 2017 sebesar 117,58 kg (Manado Post, 23 Oktober 2018. https://manadopotsonline. com/read/2018.10.23/Indonesia-Surplus Beras285-Juta-Ton- selama-2018- Ini- Kata-Pengamat/ 47827). Dengan demikian konsumsi beras per kapita per tahun di kedua desa penelitian melebihi angka rata-rata propinsi di Indonesia. 
Kalau memperhatikan dari konsumsi beras tampaknya petani di Mopait lebih makmur dibandingkan di Pangian karena mereka menambah konsumsinya dengan pangan lain. Petani di Desa Pangian kosumsi berasnya tinggi, hal ini berkaitan dengan ketahanan pangannya yang rendah. Bisa jadi juga berkaitan dengan etnis jang sejak turun temurun memang mengkonsumsi beras yang banyak. Kenyataan di lapangan menunjukkan hanya sebagian kecil beras yang dibeli atau dipinjam dari penggilingan berkisar $8 \%$ dari konsumsi total keluarga.

\section{Betulkah ketahanan pangan digerogoti pasar?}

Beras sudah menjadi komoditi pasar. Petani padi merupakan salah satu pelaku pasar yang paling lemah daya ekonominya. Ketika panen petani langsung menjual sebagian besar hasil pertaniannya karena memerlukan uang tunai. Pada saat penawaran banyak tetntunya harga menjadi lebih rendah. Jika nantinya petani harus membeli beras karena kebutuhan rumahtangganya maka harga sudah mengikuti harga pasar.

$$
\text { Bagaimana pasar mengerogoti }
$$

ketahanan pangan petani padi sawah? Lihat Tabel 2.

Tabel 2. Pasar dan ketahanan pangan petani padi sawah

\begin{tabular}{lcc}
\hline \multirow{2}{*}{ Keterlibatan Pasar } & \multicolumn{2}{c}{ Desa } \\
\cline { 2 - 3 } & Mopait & Pangian \\
\hline & ---- Garis Ketahanan Pangan-------- \\
Kecukupan pangan (KP) & 1,29 & 0,54 \\
Konsumsi Beras Keluarga (KBK) & 7,63 & 4,46 \\
\hline
\end{tabular}

Tabel 2 menunjukkan betapa kuatnya ketahanan pangan petani padi sawah seandainya tidak terlibat dengan pasar sama sekali. Ini artinya petani sama sekali tidak menjual hasil panennya. Garis Ketahanan Pangan pada angka 7,63 dan 4,46 artinya petani mampu menyimpan persediaan berasnya sampai sekita 6 tahun (Mopait) dan 3 tahun (Pangian) ke depan. Tapi apakah mungkin petani padi sawah sama sekali tidak berhubungan dengan pasar? Hal ini tidak mungkin karena komoditi hasil industri dari perkotaan sudah jauh dan luas menrangsek ke pedesaaan. Petani membeli kebutuhan hasil industri yang tidak bisa diproduksinya sendiri.

Dalam skala nasional fenomena ini memerlukan perlindungan dari pemerintah melalui mekanisme impor beras kalau pasar sedang bergejolak sehingga petani padi sendiri tidak kesulitan membeli beras bila membutuhkan. Bila pembangunan bias karena terlalu memihak industri petani khususnya petani beras dikendalikan oleh pemeringah melalui mekanisme kebijakan harga beras yang melindungi pekerja industri. Siapakah yang melindungi petani? Tidak ada. Petani ketakukan sendiri seperti anak yatim piatu. Ketika hama menyerang tidak tahu hendak mengadu kepada siapa. Tempat mengadu mungkin saja ada tetapi yang melakukan aksi langsung di lapangan tidak ada. Petani harus mengatasi sendiri.

\section{Petani padi sawah kekurangan beras}

Petani padi sawah kekurangan beras sepertinya aneh di telinga. Tetapi di lapangan terjadi. Biasanya kekurangan beras itu menjelang panen karena persediaan beras sudah habis sedangkan panen belum terjadi.

Petani yang mampu menanam tiga kali setahun dan lahannya milik sendiri, lebih aman dibandingkan yang hanya menanam dua kali atau satu kali setahun. Apalagi lahannya milik orang lain. Namun sekali lagi karena kebiasaan petani menjual sebagian besar hasil panennya demi memenuhi keperluan uang tunai, maka gejala kekurangan beras untuk kebutuhan keluarga menjadi menyebar sepanjang tahun tidak hanya dimasa-masa paceklik menjelang panen. Ketika kebutuhan uang tunai sangat besar sehingga terpaksa menjual hampir semua hasil panen, maka dibulan-bulan berikutnya sudah harus membeli beras. Bagaimana kalau tidak ada uang tunai? Keterlibatan penggilingan memberi pinjaman beras sangat lumrah. Namun sudah pasti tidak ada makan siang gratis. Penggilingan mengikat petani peminjam untuk menggiling hasil panennya pada panen yang akan datang. Pasar bisa memberikan pertolongan tetapi pertolongan itu ada harganya. 


\section{Rasio ketakutan petani (RKP)}

Petani padi sawah ternyata memendam rasa ketakutan produksi sawahnya bakal tidak memenuhi kebutuhan pangan keluarganya. Tabel 3 menunjukkan petani di Desa Mopait dan Pangian berbeda karakter. Petani padi sawah di Desa Mopait ternyata sangat pesimis. Mereka ketakutan tahun ini, 5 tahun yang lalu dan 5 tahun yang akan datang. Sedangkan petani di Desa Pangian merasa optimis produksi sawahnya mampu mencukupi kebutuhan pangan keluarga.

Tabel 3. Rasio ketakutan petani padi sawah

\begin{tabular}{lcc}
\hline Rasio Ketakutan Petani & \multicolumn{2}{c}{ Desa } \\
\cline { 2 - 3 } & Mopait & Pangian \\
\hline Tahun ini & 0,80 & 1,40 \\
Lima tahun yang lalu & 0,40 & 1,00 \\
Lima tahun yang akan datang & 0,46 & 2,71 \\
\hline
\end{tabular}

RKP > 1 berarti suasana menunjukkan optimis tidak ketakutan

RKP $<1$ berarti suasana menunjukkan pesimis ketakutan

Petani padi sawah di Desa Mopait tahun ini rasa ketakutannya lebih berkurang dibandingkan 5 tahun yang lalu. Tetapi untuk 5 tahun yang akan datang mereka tetap lebih pesimis dibandingkan tahun ini. Trauma serangan hama, kekurangan modal dan perubahan iklim yang tidak menentu membuat petani tidak bisa lepas dari rasa ketakutan panennya gagal. Apa kaitannya dengan Garis Ketahanan Pangan (GKP) di Desa Mopait yang > 1. Hal ini bisa dijelaskan karena adanya rasa pesimis ketakutan, petani lebih bekerja keras dan lebih hemat mengkonsumsi beras. Berlaku dalam keadaan tertentu mereka mencampur beras dengan jagung untuk pangan keluarga. Bila usahatani jagung dinilai lebih menguntukan secara ekonomi maupun secara iklim dan hama, maka petani tidak segan-segan menanam jagung.

Petani padi sawah di Pangian lebih optimis. Namun karena rasa optimisnya itu, tingkat konsumsi per kapita di Pangian cukup tinggi. Walaupun GKP $<1$, petani di Desa
Pangian tidak ketakutan bahkan untuk 5 tahun yang akan datang mereka sangat otimis kebutuhan pangannya akan tercukupi (RKP $=$ 2,71).

\section{KESIMPULAN DAN SARAN}

\section{Kesimpulan}

1. Jumlah komsumsi beras per kapita per tahun petani padi sawah, dari petani padi di Desa Mopait, konsumsi berasnya adalah 121 beras per kapita per tahun. Sedangkan petani padi sawah di Desa Pangian konsumsi berasnya adalah $185 \mathrm{~kg}$ beras per kapita per tahun.

2. Pada saat petani padi sawah di dua desa penelitian kekurangan beras dan tidak mampu membeli di pasar maka keluarga petani padi sawah akan meminjam beras di penggilingan.

3. Garis ketahanan pangan di dua desa penelitian menunjukkan angka yang berbeda di Desa Mopait $>1$ sedangkan di Desa Pangian $<1$. Artinya Tingkat ketahanan pangan pada keluarga petani padi sawah di Desa Mopait lebih tinggi dibandingkan dengan Desa Pangian. Sedangkan Petani padi sawah di Desa Mopait tahun ini rasa ketakutannya lebih berkurang dibandingkan 5 tahun yang lalu. Tetapi untuk 5 tahun yang akan datang mereka tetap lebih pesimis dibandingkan tahun ini. Petani padi sawah di Pangian lebih optimis.

\section{Saran}

Petani padi sawah di dua desa penelitian yaitu Desa Mopait dan Desa Pangian perlu mendapat perhatian dari pemerintah agar dapat meningkatkan produktivitas mereka masing-masing. Namun petani padi sawah di Desa Mopait sangat memerlukan bantuan untuk mengatasi masalah serangan hama kepinding tanah dan juga keterbatasan air. 


\section{DAFTAR PUSTAKA}

Mahbubi, Akhmad. 2014. "Model Dinamis Supply Chain Beras Berkelanjutan dalam Upaya Ketahanan Pangan Nasional." Jurnal Manajemen \& Agribisnis 10, no. 2: 81-89.

Neuman, Lawrence William. 2007. Basics of social research qualitative and quantitative approaches. Pearson Allyn and Bacon.
Manginsela, Elsje Pauline. 2017 “Gender and forest management local knowledge and practices in forest community". PhD, Thesis for Doctoral degree for Community and Environmental Planning in Griffith School of Environmental in Griffith University. Brisbane. QLD. Australia. 